\title{
Effects of Urban Transformation on Transportation Infrastructure: Goztepe Transformation Area Example
}

\author{
Gulcin ALP a, Yavuz OZDEMIR a, *, Sahika OZDEMIR a \\ a Graduate School of Natural and Applied Sciences, Istanbul Sabahattin Zaim University, Istanbul, Turkey \\ *Corresponding author email: yavuzytu@gmail.com
}

DOI: https://doi.org/10.34256/ajir20116

Received: 28-11-2019

Accepted: 11-03-2020

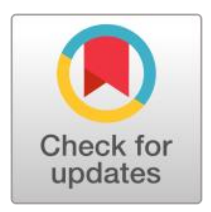

\begin{abstract}
Cities are the settlements they form as living spaces of societies and they are not just structures; the same people are born, breathe, grow and thrive. While the cities are growing, their structures are unable to carry the density of the population due to deterioration in time. Urban transformation projects have emerged as a response to this need. However, it is seen that there are some problems and deficiencies when the issue of existing land use and transportation network factors for renewal of the problematic places of the cities is examined in parallel with the changes. If these problems are not prevented, it will not be possible to leave quality, reliable and sustainable cities for years to come. Non-sustainable transportation and land-use decisions in fast-growing urban areas are not effective in solving transportation problems. Point solutions against transportation problems are not permanent in the long term and cause problems after a short period of time. Therefore, the effect of the transformations on the transportation and land use factors are evaluated together. In this study, it is emphasized that the land use and transportation factor should be handled based on Göztepe District of Bağcllar district which is in the process of transformation under the law no 6306.
\end{abstract}

Keywords: Urban transformation, Sustainability, Transportation, Planning.

\section{Introduction}

Cities are settlements formed by societies as living spaces and they are not only buildings; they are born and breathing just like humans. While the cities are growing, some negative changes occur in their structures and they become unable to carry the population density in time. At this point, transformation projects emerge as a process that can meet the need. However, it is seen that there are some problems and inadequacies in terms of how suitable and parallel the existing land use and transportation network factors are for renewing the problematic places of cities. When these problems are not prevented, it will not be possible to leave quality, reliable and sustainable cities for the coming years.

In every part of the city life, the most important factor that directly or indirectly affects people positively or negatively is 
transportation (Gilat, 2002). Planning, investments and development dynamics are cases that need to be considered in a coordinated manner in every case where transportation is handled. However, the relationship between land use and transportation has a higher share than all these, and it is the most important point to be used in determining the factors that play a role in the formation of all the above mentioned factors (Giuliano, 1989).

For sustainable transportation planning, point transformations that will increase the density on the axis of people and transportation should be avoided and more regional studies should be emphasized.

\section{Basic Concepts and Literature Review}

\subsection{Urban Transformation Concept}

When urban transformation is considered, firstly the term urban and then the term transformation are the concepts to be dealt with.

The cities where people have lived together for years are not only structures. Cities, just like humans, are born, grow, breathe, develop with people and wear and tear over time (Ergun, 2010). The studies carried out with the aim of getting rid of these situations in which the cities live provide the concept of urban transformation.

Urban transformation is not a spontaneous process. Urban transformation takes place in the form of external interventions to cities for social, economic, cultural and political purposes (Keles, 2012). Usually, the city, low-income groups living in bad economic and physical conditions or lost their population and social solidarity lost in residential areas, old empty ports and industrial areas in the form of implementation of projects that will contribute to the economic development of the city (Ataov and Osmay, 2007).

Urban transformation, which has entered our lives as a new concept in today's conditions where urban populations are gradually increasing, can be defined as restructuring of an urban area in a certain time frame by creating job opportunities for redevelopment, improving infrastructure conditions and providing environmental renewal (Ergun and Gul, 2010).

Today the most discussed and in Turkey, which is one of the urban transformation of the discussed issues on economic, social and political being investigated by many sectors. The concept of urban transformation, which is on the agenda, has many definitions that come to the same door but are tried to be explained in different ways. The reason for this is that the urban transformation process differs according to the economic, political and social conditions of the countries in terms of scope and purpose (Aydinli and Kaya, 2013).

Cities are in constant motion. The usage of the lands changes and the lands are renewed. Cities are expanding over time and rarely, though occasionally, smaller. There are many reasons for changing the way land is used, such as economic, environmental, social needs, or bringing them together (Jones and Evans, 2008). In this context, attempting to solve these economic, environmental and social factors in the transformation of cities reveals the transformation.

\subsection{Dimension and Objectives of Urban Transformation}

Urban transformation is a comprehensive process with its physical, social, economic, legal and administrative dimensions as well as its design and planning dimension.

In urban transformations, the role of planning and design dimension is important 
for a healthy transformation process and good quality of life. Urban Design is a physical intervention in order to improve the environmental quality of a defined space within the general principles of the implementation zoning plan. While this physical intervention occurs in the form of regulation of public spaces, it is also mentioned as intervention in private property areas in order to improve the quality of the environment (Yarar, 2003).

The physical dimension deals with transport links with the region, housing stock, technical and social infrastructure and environmental problems. The design dimension includes the urban design process that guides physical development, change and conservation (Sisman and Kibaroglu, 2009).

The social dimension deals with conditions such as health, education, access to housing and public services, crime, exclusion from society, participation of public and private sector, local people and volunteers in the project process. In addition to the transformation to improve the physical space, the population living and living in the area to be transformed should not be ignored; economic structure, cultural characteristics, customs and traditions, education levels are examined, the most appropriate living conditions for this population should be determined by applying transformation (Dukkanci, 2013).

The economic dimension involves increasing the quality and quantity of job opportunities in and around the selected area. Economically good societies improve the standard of living and leave healthy urban parts to their environment and future generations. In this regard, creating socioeconomically developed community segments should be included in the objectives of local governments (Roberts and Skyes, 2000).
One of the most problematic areas that affect the process in urban transformation practices is the legal and administrative dimension. Procedures and practices for the urban area to be transformed are shaped by legal and administrative decisions.

Urban transformation is difficult to implement unless regulated within the legal system. In order to be successful, the relevant laws must work in harmony and coordination with each other (Ozden, 2006). Because in urban regeneration projects, conflicts may arise because they involve the relationships of different interest groups. Therefore, there is a need for a general transformation law which includes the approaches and principles of transformation. In particular, shaping the locally developed transformation projects in line with the decisions of the master plan will ensure urban integrity, disagreements that will arise during the process will be solved quickly and the continuity of the project will be ensured.

Urban Transformation has emerged to respond to five main objectives.

- The first step is to examine the causes of social deterioration, to eliminate the problems and to prevent the collapse of urban spaces,

- To be able to provide answers to the physical needs of the city in time

- To be able to put forward a model of economic development with a continuity that will increase the quality of the city's welfare

- To ensure the efficient use of the existing areas of the city and to determine the policies that can prevent the irregular urban sprawl.

- Ensuring the participation of nongovernmental organizations and different segments of society in the planning to meet the need to shape urban policies as the product of social opportunities and political forces. 


\subsection{Urban Transformation in the World}

\subsubsection{Spain Barcelona Transformation Project}

Barcelona, Spain's second largest city, is located in the northeast of the country. Barcelona, one of the Mediterranean's most important ports and trade centers, is one of Spain's tourist, commercial and financial centers with its unique culture and planning.

II. World War II changed the economic and population balances of many cities. Spain, which did not enter the war, was affected by this process and its cities were negatively affected. Barcelona, one of these cities, has also changed its appearance due to physical and social deterioration. The modern transformation of Barcelona began with the impetus of preparations for the 1992 Barcelona Olympics. In 1986, multiple participation and interdisciplinary studies were initiated to solve the problems of the city. Participants of the transformation project;

- Barcelona City Council

- Local government

- Private sector

- Non-Governmental Organizations.

Barcelona's most important problems before the transformation; density, unplanned urbanization, lack of infrastructure and social equipment areas, social and security problems. The objectives of urban transformation determined in this direction are;
- Decreasing the density of urban areas and producing open spaces,

- To raise living standards,

- Creating infrastructure and social reinforcement areas,

- Increasing security,

- Encouraging public external rehabilitation.

Between 1988 and 2002, a total area of $107,000 \mathrm{~m} 2$ was re-evaluated and a total of 279 streets, 61 squares and a city park were reorganized. Within the scope of urban renewal project, 2850 new houses, 4 social centers, 9 schools and nurseries, 5 nursing homes and 9 sports centers have been established. While new buildings were constructed for some of the housing and social centers within the scope of the project, the buildings obtained as a result of the restoration of the existing buildings in the city were used for a significant part. In addition to the rehabilitation of public areas, green spaces and urban areas, infrastructure projects such as the renovation of parking lots and transportation networks have been implemented along with the technical infrastructure. In other words, the project has not only been seen as restoration but has been implemented as a whole with other dimensions as it should be (Figure 1) (Budak, 2007).
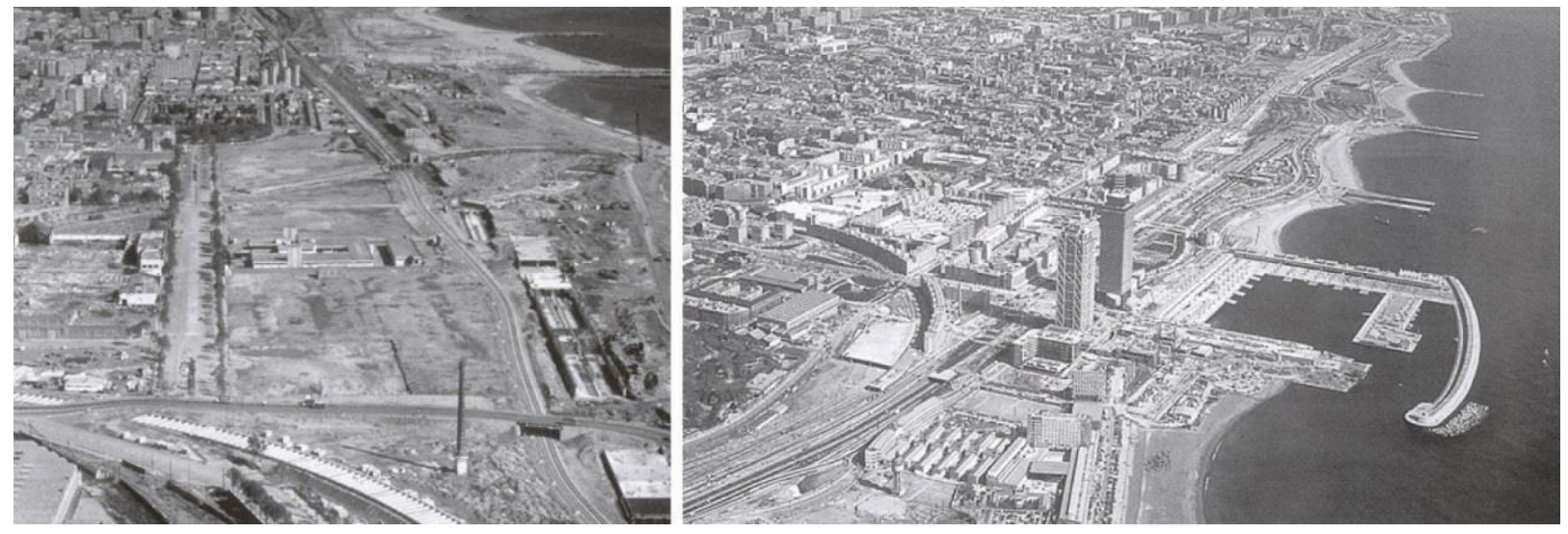

Figure 1. Before and after Barcelona Olympic Field (Dayioglu, 2006). 


\subsubsection{Hiroshima-Danbara City Urban Transformation Project (Japan)}

The atomic bomb that was assigned to Hiroshima on August 6, 1945 killed 140,000 people and destroyed an area of $13 \mathrm{~km} 2$. The atomic bomb destroyed not only the death of people, but also the transport and communication facilities in the area, water and sewerage systems and buildings. The reconstruction of Hiroshima was discussed in the context of the restructuring project of the national government (URL 1). Such a major destruction caused the region to restructure and the project started in 1945 was completed in 1995 (Boyraz and Hos, 2014).

The Danbara urban transformation project has been implemented both to build the most beautiful city in the world and to create an industrial city. With its natural beauty and culture, it was aimed to establish a settlement area that would serve world peace and set an example for other countries. The Danbara project is the beginning of a wellplanned small-scale rebirth movement (Gunes, 2013). The main purpose of the project is to make Hiroshima attractive to live and work again. The project, which was planned to be completed in 1995, was approved in 1973 and started in $1983.62 \%$ of the buildings have been built until the date of completion. The project was realized not only with the public hand but with the participation of the private sector and local people (URL 2). 461 of the buildings were built by the private sector. The buildings constructed between 7 and 10 floors are built on the main roads and used as both residential and business premises. The total cost of the project is 283.8 million dollars. $57 \%$ of this cost came from Hiroshima city, 38\% from local governments and 5\% from other private sources (Sisman and Kibaroglu, 2009).

The objectives of Danbara city urban transformation project are as follows (Kara, 2007: 3):

- To be able to find solutions to the housing problem of low-income people in the region Producing large scale active green area
- To meet the needs by establishing a systematic relationship between the public and the municipality.

- Mass housing construction involves the renovation of destroyed or damaged houses and the construction of safer and more comfortable areas (URL 3).

Another aim of the Danbara project is to build spaces where young people and adults can spend time and relax. As of 1995, 5 park areas, 2 green areas and 13 playgrounds were established in Danbara. The park and playgrounds are built to reflect the traditional character of the region. In addition to this, 4,761 meters of main road and 10,457 meters of secondary road construction were realized. 21 organizations were established by the public for the project and 12 of them played an active role in the decision-making process of the plans. Participation of the people in the decision stage has added aesthetics to the studies conducted in poor regions (Sisman and Kibaroglu, 2009).

During the construction of the Danbara City Urban Transformation project, the state, local people and local governments acted together and achieved an efficient result. Turkey in the field of urban transformation with the reforms recently made legal authority to local governments are given a lot (Independence, 2006). The participants in this process of local government in Turkey is a condition that occurred recently. Increasing participation in the projects is important both for the legitimacy of the project and the satisfaction of the public (Figure 2).

\subsection{Urban Transformation Practices in Turkey}

Urban transformation, there have been changes in the application of the necessary laws and regulations identified in 2012, after Turkey. In big cities, especially in Istanbul, these practices have started to be implemented and continue. 


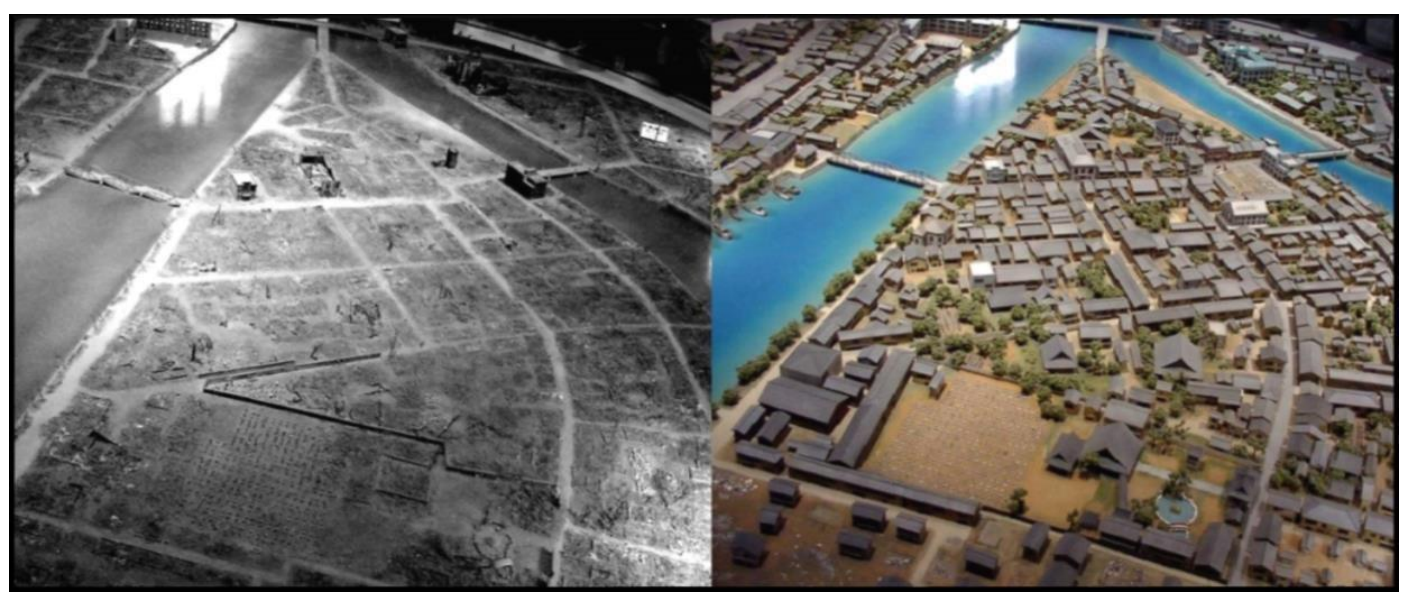

Figure 2. Before and after the field conversion (URL-4).

\subsubsection{Ayazma-Tepeustu}

\section{Transformation Project (Kucukcekmece)}

Ayazma-

Tepeustu

Urban

Transformation Project has the most comprehensive and projects to be completed as soon as possible in the title of slum transformation work in Turkey. This study was carried out with the cooperation of Istanbul Metropolitan Municipality (IBB), Housing Development Administration (TOKI) and Kucukcekmece Municipality.

Erdal (2010), in a sense, Kucukcekmece has a combination of many problematic subregions in the Istanbul Metropolitan Area. On the one hand, the important nodes on the western front of the metropolis and the transportation point, the district has natural values on the other front, the corridor of reserve areas on which it is located, the identification areas of the metropolis within and around the coastal areas (Olympic Park, Airport, Organized Industrial Zone, Wholesale Trade Areas, etc.). It is inevitable that the subregions which are problematic, unhealthy, deprived of urban quality and lack of life safety, social collapse and criminal centers in such an area will be regained as healthy and livable areas. With this acceptance, an effort has been made to protect the user in place and sometimes to change the user, but in both preferences, an effort is made to improve the socio-economic conditions, heal and reintegrate the society at the point where the user has left and / or gone. This basic objective will be based on different models according to the situation and structure of the current user who has many different profiles (status, ownership structure, ownership levels, socioeconomic structure and demographic structural features, etc.) and solution models will be constructed. Thus, in line with the social and economic programs targeted to be created with the participation of all relevant actors, it is aimed to bring these problematic areas to the stage first in Kucukcekmece and then in Istanbul.

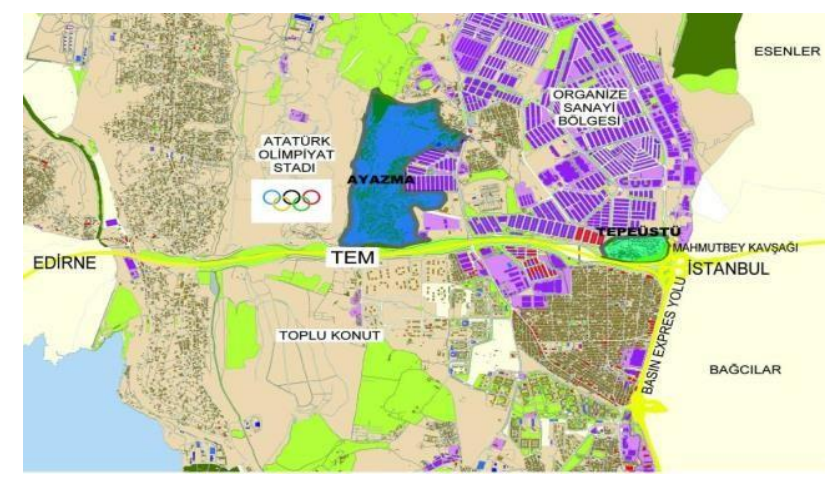

Figure 3. Küçükçekmece urban transformation areas (around Olympic Village)

The project area is located within the development area of the Istanbul Metropolitan Area and the majority of the land has been developed unplanned on the treasury land. The region, which is generally composed of low-rise slums, lacking spatial quality, is extremely insufficient in terms of technical infrastructure and social equipment. Since the 
income level and education level of the people of the region are at low levels, economic collapse is also experienced. In addition, unhealthy living conditions as well as the presence of structures near the creek bed, the risk of natural disasters, are other factors that threaten life safety. As a pilot project, priority was given to the region which could not be physically and socially associated with the environment and could not integrate with the city due to all these negativities (Figure 3).

\subsubsection{Ayazma Location}

There is a reserve corridor to the north of the area that rests on the TEM.

- It is located to the east of the Olympic Park and to the west of the OSB.

- It is an unplanned developed area.

- This area is largely illegally built on treasury property.

- Usually consists of single storey buildings.

- It is a region lacking social equipment and technical infrastructure.

- The income level of the people living in the region is low and it is a social depression area (Figure 4).

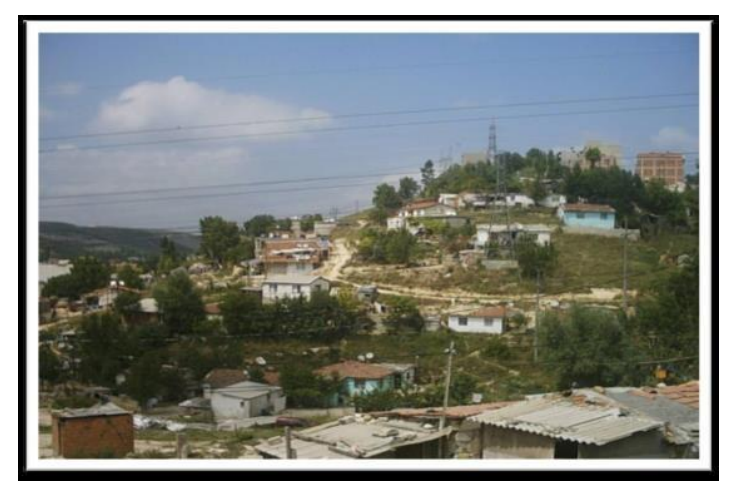

Figure 4. Pre-Project Ayazma Region 1 (Kucukcekmece Municipality, Planning and Project Directorate, Urban Transformation Directorate).

\subsubsection{Tepeustu Location}

- There is a reserve area corridor to the north of the area that rests on TEM in the south.

- It is located to the east of the Olympic Park and to the south of the OSB.
- It is an unplanned developed area.

- This area has been illegally constructed on the treasury property.

- The region consists of single storey buildings.

- It is a region lacking social equipment and technical infrastructure.

- The income level of the people living in the region is low and it is a social depression area (Figure 5).

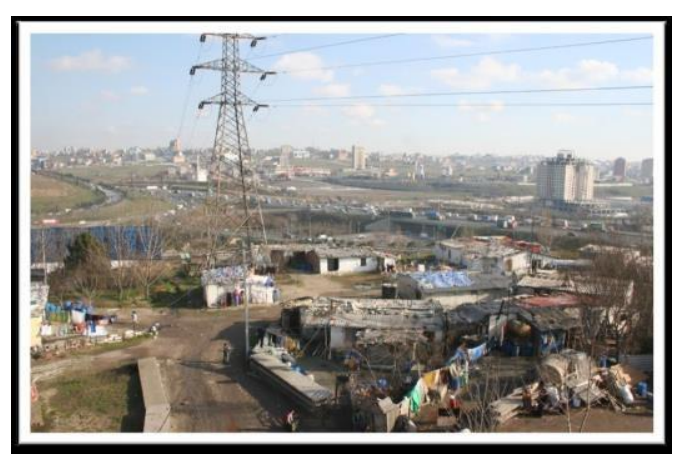

Figure 5. Pre-Project Tepeüstü Region 1 (Kucukcekmece Municipality, Planning and Project Directorate, Urban Transformation Directorate).

\subsubsection{Fikirtepe Urban Transformation Project}

The project has started on 28.03.2006 and according to the Law No. 6306 on the Transformation of Disaster Risk Areas, the urban transformation area has been declared due to irregularity of existing structures and insufficiency of reinforcement areas in the area and lack of open and green areas.

The project area is approximately 134 hectares. In terms of area, it can be expressed as the biggest urban transformation area of our country (Figure 6).

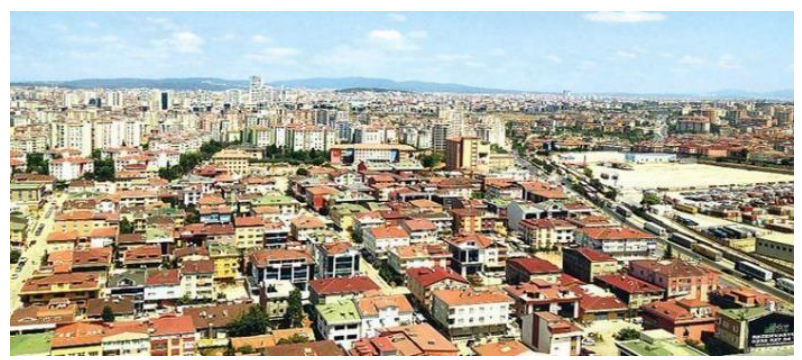




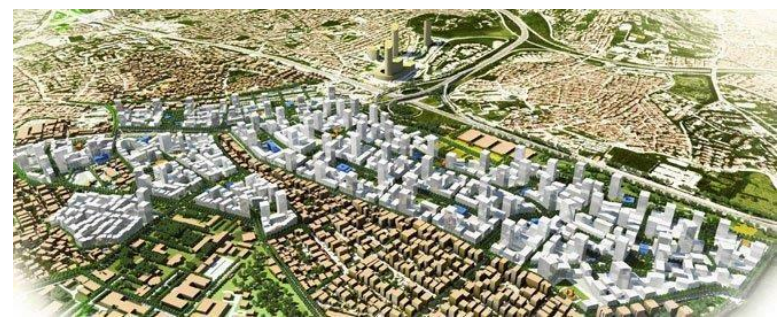

Figure 6. View Before and After Fikirtepe Zoning Plan (Fikirtepe Urban Design Framework)

\section{Materials and Methods}

Within the scope of Law No. 6306 on the Transformation of Disaster Risk Areas in Goztepe Neighborhood and its immediate surroundings, the impacts of risky area announcements on transportation function in terms of planning integrity were examined and suggestions were made.

Firstly, the conceptual framework has been considered and the relationship between transportation, land planning and urban transformation has been put forward theoretically. Therefore, the literature review is applied in these sections. It is examined how land use and transportation problems are handled with the current practice within the scope of urban transformation.

\section{Urban Form, Transportation-Land Use}

Planning, investments and development dynamics are the facts that should be considered as coordinated in every situation where transportation is handled exactly. However, the relationship between land use and transportation has a higher share than all these, and it is the most important point to be used in determining the factors that play a role in the formation of all the above mentioned factors (Giuliano, 1989).

Cities are developing organisms, and the relationship between transportation and land use cannot be considered independently of each other. To be a sustainable accessible transformation, the concept of urban transformation should be considered as an opportunity for the creation of healthy livable cities.

\subsection{Urban Form and Affecting Factors}

Cities have evolved in different forms, sometimes according to needs and sometimes according to geographical conditions. The urban form usually arises directly from the actual geographical location of the city. The factors affecting the urban form - in general terms - are population movements and migration, economy, social structure, policy, environment, technology, disaster (earthquake), transportation, distribution of equipment and infrastructure (Aktan Aktuglu, 2006).

In general, we can examine the factors affecting the urban form under four main headings. The first of these is the geographical inputs that transform the city necessarily in shaping the shape of the city that shapes the development of the city. The second is demographic structure and migration movements. Thirdly, we can show economic activities shaped by population and period conditions. Finally; It is the transportation and accessibility factor on the parts of the land where the city develops.

\subsection{Transportation and Land Use Relationship}

From the establishment of the first settlements with low population to the development of today's crowded metropolises, transportation is one of the main issues that enable human actions. Transportation is one of the main forces in the formation, shaping and growth of human agglomerations which are the products of complex interactions in the historical process (Vuchic, 1981). Transportation emerges with demand in line with the needs and aims of the people, and it serves to people and communities under the condition of technological opportunities of the day. Demand is related to the potentials of any place-space.

The evaluation / utilization of these potentials necessitates the construction of the transportation network. Urban reinforcement areas, such as stops, wharfs, terminals, which 
connect the different land use functions of a settlement and provide access from one place to another are also within the scope of transportation. In addition, transportation is one of the areas where the first applications are realized and directly affected by the developing technologies throughout human history. There is a strong bi-directional impact between transport and land use. They cannot be considered independent and are in a continuous cycle.

Expected transport demands in the future depend on the urban structure to be formed according to land use decisions. The interaction between land use structure and transportation system is two-way. The land use structure of the city (population, employment, industry, trade, schools, housing areas, distribution of MIA's) determines the transportation demand on the roads of the city (Gercek, 1996).

There is a close interaction between land use and transport patterns that shape the urban fabric. Handy, Greenwald and Boarnet tested the hypothesis that urban elements with short distances in economic activities could increase the number of urban journeys on foot and that these kinds of trips could replace vehicle journeys (Greenwald and Boarnet, 2001). Similarly, Vernez-Moudson and Hess found an empirical study in which they examined the effects of residential and commercial land use in the Puget Sound Region, positively affecting pedestrian journeys (Vernez-Moudon, 2003). Ewing et al. Another empirical study by Palm Beach, Florida, USA, showed that differences in job opportunities and housing density at the local level, mixed residential and commercial land use, and transportation system design reduced the number of kilometers covered by car. (Ewing et al., 1994).

As the urban form changes over time, the land use and transport network changes very slowly, but the movements resulting from the combination of land use and transport (movements between work-population, tradefreight transport, working and housing areas) change much faster and adapt to the city.
5. The Relationship Between Transportation and Transformation from Goztepe Neighborhood

\subsection{Bagcilar District Location and Geographical Situation}

Bagcilar district; It is located on the European side of Istanbul, within the borders of Metropolitan Municipality. Edirne- made in Ankara, Turkey's most important highway of the E-80 (TEM) of this route via the motorway $0-2$ route $D 100$ (old E-5) highway, southwest and north-eastern express link between the Bagcilar district of passage feature. It is surrounded by Kucukcekmece in the west, military land and Esenler in the north, Gungoren in the east and Bahcelievler in the south.

Looking at the geographical features of the district; The district of Bagcilar has been formed by abrasion, it spreads on a flat and undulating plateau and its altitude varies between 50-70 meters. The length of the streams in the district which has no coastline is very small and their regimes are irregular. Cobancesme and Tavukcu streams feed the region from the north-south axis.

\subsection{Bagcilar District Current Transportation and Planned Transportation Investments}

The TEM 0-3 Connection continues along the north-east of the area, while the north-west is limited to Sumeyye Street. Maslak Street passes south of the area. The intersection of Maslak and Kazim Karabekir Street; It shows the south west of the urban transformation area. On Sumeyye Street direction, there are Onder Street and Oya Street, and there is also a minibus stop within the area boundary and a bus stop on Maslak Street (Figure 9).

Urban development, supported by road transport investments, is gaining a new dimension with the intensification of rail systems especially in this region in the $1 /$ 100.000 Istanbul Environmental Arrangement Plan and it is aimed to increase accessibility to 
the region. Bagcilar district contributes to the housing of the labor force coming to the Organized Industrial Zone. The Goztepe neighborhood attracts attention especially with its proximity to the business centers to the north of the TEM-03 connection passing north.

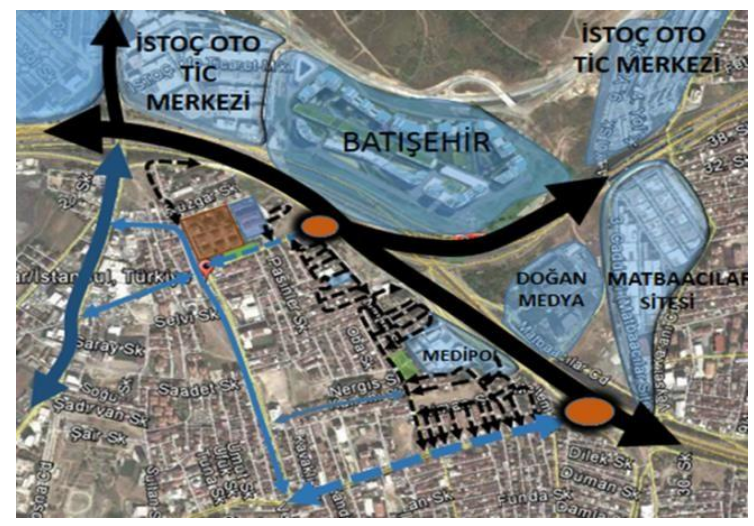

Figure 9. Bagcilar District Current Transportation Axles.

The Kabatas - Mecidiyekoy Mahmutbey Metro Line, which is under construction in the region, is planned as a rail system line with a total length of 19 passenger stations and approximately $24.5 \mathrm{~km}$ in length. On this line; The construction of two separate lines, Kabatas - Mecidiyekoy with a length of $6.5 \mathrm{~km}$ and the route of Mecidiyekoy Mahmutbey with a length of $18 \mathrm{~km}$, was started in 2014. Kabatas - Mecidiyekoy Mahmutbey Metro Line; Kabatas, Besiktas, Yildiz, Fulya, Mecidiyekoy, Caglayan, Kagithane, Nurtepe, Alibeykoy, Circir, Veysel Karani-Aksemsettin, Yesilpinar, Kazim Karabekir, Yenimahalle, Karadeniz Neighborhood, Giyimkent-Tekstilkent, Oruc Reis, Goztepe, Mahmutbey stations (Figure 10).

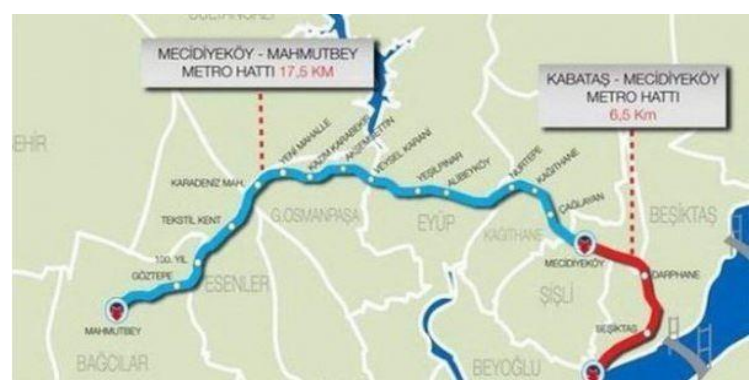

Figure 10. Planned Mecidiyekoy - Mahmutbey Subway Line.
Car parks under construction in the region Goztepe neighborhood, Ufuk street underground parking lot is estimated to be 2019 with a capacity of 169 vehicles and a physical realization rate of $85 \%$, and Mecidiyekoy - Mahmutbey metro line Mahmutbey station parking is estimated to be 2019 with a 360 vehicle capacity and a realization rate of $80 \%$.

According to the Article 2 of the Law No. 6306 on the Transformation of Areas at Disaster Risk on the letter of 120 dated and 9/1/2013 of the Ministry of Environment and Urbanization, Goztepe Neighborhood a risky area has been declared (Figure 11).

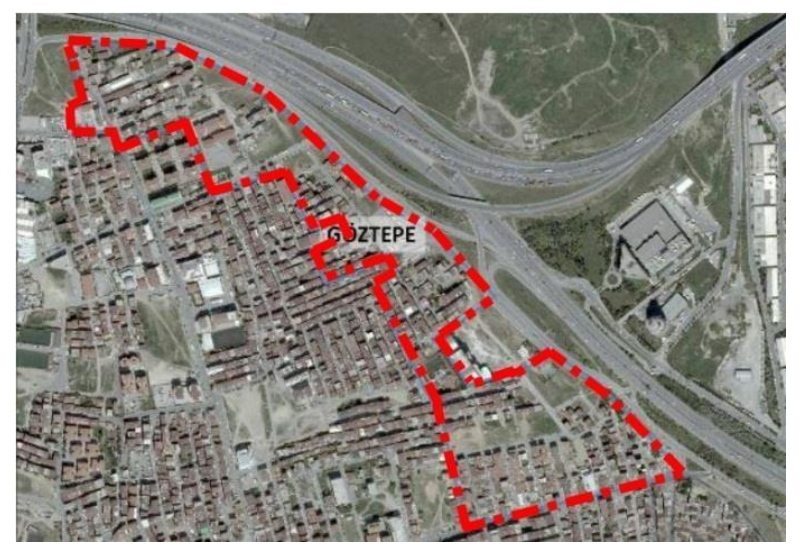

Figure 11. Risky area declared Goztepe neighborhood.

Area Size: $206,586 \mathrm{~m}^{2}$

Area Population: 5394 people

Building Number: 453

Number of Houses: 1971

Number of Property: 1553 people

\subsubsection{Goztepe Neighborhood Physical Structure}

When the land use in the area is examined, $31.07 \%$ of the parcels are reserved for residential use and $4.37 \%$ for residential + commercial use. This ratio shows that most of the area belongs to residential use (Table 1).

When the purpose of usage of independent units is examined, $86.34 \%$ of the units are used as households and $13.66 \%$ are used as workplaces. 
When the floor type of the independent units is examined, the floor type of the major units appears to be Normal. The remaining independent units are located in the basement, ground and attic.

$73.80 \%$ of the individuals living in Goztepe Neighborhood were identified as rights holders, $15.28 \%$ as tenants and the remaining $10.92 \%$ as users. Individuals referred to as users are usually close relatives of rights holders and live in independent units free of charge. It is seen that the majority to be moved during the transformation are rights holders.

Table 1. Goztepe Neighborhood Land Use Table

\begin{tabular}{|l|c|}
\hline \multicolumn{1}{|c|}{ LAND USE } & Hectare \\
\hline Housing & 6,4 \\
\hline Trade + Housing & 0,9 \\
\hline Trade + Service & 0,7 \\
\hline Green area & 0,5 \\
\hline Industry & 0,08 \\
\hline Empty Parcels & 6,3 \\
\hline Training Facility & 0,9 \\
\hline Religious Facility & 0,1 \\
\hline Health Facility & 0,02 \\
\hline Roads & 4,7 \\
\hline
\end{tabular}

\section{Conclusion and Suggestions}

In this study, Goztepe neighborhood, which is declared as urban transformation area by Bağcllar District with the law no. The mentioned area has been declared as risky area within the scope of the Law no. 6306 and it is being planned again. It has been mentioned how the transportation should be handled in the re-planning of this region, what the potentials of the area are and what the planned investments are.

Considering the transportation factor for a successful urban transformation project, it is necessary to make a holistic planning rather than a piecemeal when planning land use, and to determine the expectations of the users, the existing potentials and trends of the areas, and to take into account the identities of the cities and the sustainable transportation and land use planning. It is possible that the result is encountered.

Within the scope of the study, urban transformation decisions should be taken in a holistic and not programmatic manner and integrated with the transportation plans of these regions. For example, when determining a subway location designed on a macro scale, urban transformation should be taken into consideration and feeder connections with micro subway, bus, minibus lines should be arranged, designs to increase the mobility of pedestrian and bicycle should be taken into consideration and parking need of the region should be taken into consideration.

In the physical transformation of the city while spatial planning is made, mixed land use and transportation decisions should be taken, pedestrian-friendly designs should be encouraged, pedestrian transportation should be encouraged, motor vehicle traffic should be implemented and mechanisms that control this should be established and sanctions should be applied.

When the law is established, a board should be determined during the planning process after a region is declared as an urban transformation area and experts from different disciplines should be included in this board. The event should not be solved only by a centralized policy, but should be taken by a committee of NGOs, university professors, officials from different occupational groups, politicians and even public representatives.

In physical planning, transportation networks should be determined according to the current and proposed demand and supply, taking into account the population after numerical data and studies. Public transport routes should also be handled in this context. Bus-minibus routes and even subway stops should be recommended. Urban transformation areas should be identified in the transportation master plans and an integrated transportation network planning should be made with the other transportation axes of the city. 
Urban transformation areas should be identified in the transportation master plans and an integrated transportation network planning should be made with the other transportation axes of the city.

\section{References}

Ataov, A., and Osmay, S., (2007). "Methodological Approach to Urban Transformation in Turkey". Metu, 24(2), 57-82.

Aktan Aktuglu, E., (2006). "Approaches to Urban Form - Transportation Interaction (Historical and Current) and Istanbul Case”. PhD Thesis, Yildiz Technical University, Graduate School of Natural and Applied Sciences, Istanbul.

Aydinli, H.I., and Kaya, A., (2013). "Problem Areas in Turkey with the Urban Renewal Application Examples Judgments". Afyon Kocatepe University İIBF Journal, 15(2), 449-468.

Boyraz, Z., and Hos, B.Y., (2013). "Urban Transformation Practices in Turkey". Journal of World of Turks, 6(3), 45-63.

Budak, B., (2007). "Gentrification in the Context of Urban Renewal Process: Example of Fener Balat". Master Thesis, M.S.G.S.U., Graduate School of Natural and Applied Sciences, Istanbul.

Dayioglu, O., (2006). “Transformation Projects in Urban Development: Definition of Process and Actors, The Case of Zeytinburnu". Master Thesis, Istanbul Technical University, Graduate School of Natural and Applied Sciences, Istanbul.

Dukkanci, U., (2013). "Investigation of Urban Development and Transformation Process of the current legal-administrative Size in Turkey". Master Thesis, Yildiz Technical University, Graduate School of Natural and Applied Sciences, Istanbul.

Erdal, N., (2010). "Determination of User Satisfaction in Urban Renewal
Applications: Kucukcekmece Ayazma Renewal Application". Master Thesis, Istanbul Technical University, Graduate School of Natural and Applied Sciences, Istanbul.

Ergun, C., and Gul, H., (2010). "Urban Transformation Projects in the Process of Violation of the Right to Housing". National Symposium on Social Rights.

Ewing, R., Haliyur, P., and Page, G.W., (1994). "Getting Around a Traditional City, a Suburban Planned Unit Development, and Everything in Between". Transportation Research Record, 1466, 53-62.

Gercek, H., (1996). "Bosphorus Crossings Depending on Land Use Scenarios within the framework of Istanbul Transportation Master Plan". First National Transportation Symposium, Istanbul: General Directorate of IETT Enterprises.

Gilat M., and Sussman J.M., (2002). "Coordinating Transportation and Land Use Planning in the Developing World: The Case of Mexico City". Massachusetts.

Giuliano, G., (1989). "New Directions For Understanding Transportation and Land Use". Environment and Planning A, 21, 145-159.

Greenwald M.J., and Boarnet M.G., (2001). "Built environment as determinant of walking behavior: Analyzing nonwork pedestrian travel in Portland, Oregon". Transportation Research Record, 1780, 33-42.

Gunes, İ., (2013). "An International Perspective on Urban Transformation in the World". Journal of Union of Municipalities of Marmara, 81, 32-37.

Jones, P. and Evans, J., (2008). "Urban Regeneration in the UK: Theory and Practice". UK: SAGE.

Kara, G., (2007). "Urban Transformation Applications". Ankara: TMMOB Chamber of Surveying and Cadastre Engineers II. 
Turkey Scientific and Technical Conference.

Keles, R., (2012). "Urbanization Policy". Ankara: İmge Publishing.

Khisty, C.J. and Lall, B.K., (2003). "Transportation Engineering: An Introduction". Prentice Hall.

Kurtulus, H., (2006). "Looking at Urban Transformation from the Collapse of Modern Urban Myth". Planlama Journal, 36, 7-11.

Ozden, P., (2006). "Applicability Thoughts on Urban Transformation in Turkey". Istanbul University Journal of Political Sciences, 35, 215-233.

Roberts P., and Sykes H., (2000). "Urban Regeneration". London, Thousand Oaks, New Delhi: Sage Publications.

Sisman, A., ve Kibaroglu, D., (2009). "Urban

Transformation Practices in Turkey". Chamber of Survey and Cadastre Engineers 12. Turkey Scientific and Technical Conference.

Vernez-Moudon, A., Cail, M., Pergakes, N., Forsyth, C., and Lillard, L., (2003). "Strategies and Tools to Implement Transportation-Efficient Development: A Reference Manual". Phase 2 of Integrating Land Use and Transportation Investment Decision Making. Washington State Transportation Center (TRAC), University of Washington.
Vuchic, V.R., (1981). "Urban Public Transportation Systems". Prentice-Hall, INC. Englewood Cliffs, New Jersey, U.S. Wegener, M., (1995). "Current and future land use models". In: Travel Model Improvement Program Land Use Modeling Conference Proceedings (G.A. Shunk, P.L. Bass, C.A. Weatherby, L.J. Engelke, eds.), 13-40. US Department of Transportation, Washington, DC

URL-1: www.pref.hiroshima.lg.jp (Date of access: 04.02.2019)

URL-2: $\quad$ www.kentseldonusumhaberleri.com (Date of access: 05.01.2019)

URL-3: www.worldhabitatawards.org (Date of access: 12.03 .2019$)$

URL-4:http://commons.wikimedia.org/wiki/F ile:HiroshimaNakajimaArea.jpg (Date of access: 15.05.2019)

Conflicts of Interest: The authors have no conflicts of interest to declare that they are relevant to the content of this article.

Funding: No funding was received for conducting this study.

About The License

(C) The author(s) 2020. The text of this article is open access and licensed under a Creative Commons Attribution 4.0 International License 